\title{
ORIGINAL ARTICLE \\ Reliability and discriminative ability of the spinal cord independence measure III (Thai version)
}

\author{
J Wannapakhe ${ }^{1,2}$, W Saensook ${ }^{2,3}$, C Keawjoho ${ }^{2,4}$ and S Amatachaya ${ }^{2,4}$
}

Study design: A cross-sectional study.

Objectives: To translate and assess the reliability and discriminative ability of the Spinal Cord Independence Measure III (SCIM III), Thai version (Th-SCIM III).

Setting: A tertiary rehabilitation center in Thailand.

Methods: The SCIM III was translated into the Thai version with a forward-backward translation. The tool was then used by three physical therapists to assess 31 subjects with various degrees of spinal cord injury (SCI) during the first week after admission.

Results: The Th-SCIM III had excellent inter-rater reliability (intraclass correlation coefficient $>0.90$ ) and good internal consistency (Cronbach's alpha $\geqslant 0.88$ ), and could significantly discriminate between the performance of subjects with varying degrees of lesion severity. Scores of 50 and over could moderately discriminate between subjects with motor complete $\mathrm{SCl}$ and incomplete $\mathrm{SCl}$ (sensitivity $68.75 \%$, specificity $66.67 \%$, 95\% confidence interval $=0.62-0.95$ ).

Conclusion: The findings support the reliability and discriminative ability of the Th-SCIM III. The tool may benefit clinical assessments for overall aspects relating to $\mathrm{SCl}$, particularly for Thai physical therapists. However, a further exploration of other psychometric properties may enhance the clinical utility of the tool.

Spinal Cord (2016) 54, 213-220; doi:10.1038/sc.2015.114; published online 14 July 2015

\section{INTRODUCTION}

Spinal cord injury (SCI) causes deterioration of motor, sensory and autonomic functions, with consequent profound effects on physical performance. ${ }^{1}$ Although patients with SCI can improve their performance after participation in a rehabilitation program, ${ }^{1-3}$ the dramatically decreased length of rehabilitation ${ }^{4}$ suggests a crucial need for an effective rehabilitation program and a thorough quantitative assessment to promote performance and to clearly quantify the functional alteration of patients.

The Spinal Cord Independence Measure (SCIM) is a quantitative tool specifically designed to assess overall performance relating to SCI. The tool was originally developed at the Loewenstein Rehabilitation Hospital by Catz et al..$^{5}$ It was later modified (SCIM II) to separate bathing and dressing for upper and lower parts of the body, with minor changes in phrasing of the scoring criteria for other functions. ${ }^{6}$ The SCIM III, the latest version, was established in 2002 to include a new item (transfer: ground-wheelchair) and slightly modified the scores of various sub-items to keep the same total score (100). ${ }^{3}$

The SCIM III covers three areas of function associated with SCI, including self-care (subscore 0-20), respiration and sphincter management (subscore 0-40), and mobility (subscore $0-40){ }^{7,8}$ The tool has been previously translated into many languages (that is, Italian, Turkish, Brazilian Portuguese and Spanish) with subsequent assessments of its applicability. ${ }^{9-12}$ To enable the utility of the tool for Thai health professionals, this study primarily aimed to translate the SCIM
III into Thai (Th-SCIM III) and to assess the reliability of the tool. In addition, the study secondarily investigated the discriminative ability of the tool in patients with various degrees of lesion severity.

\section{MATERIALS AND METHODS \\ Subjects}

The subjects were patients with SCI who were admitted to the rehabilitation ward of a tertiary rehabilitation center in Thailand, with an age at least 18 years. The inclusion criteria were SCI from a traumatic cause or nonprogressive disease, both complete and incomplete lesions (as determined using the criteria from the American Spinal Injury Association Impairment Scale (AIS)), and at a subacute or chronic stage of injury. The patients were excluded if they had any problems affecting their ability to perform daily activities, such as pain at rest or with movement with a pain score of more than 5 out of 10 on a visual analog scale, or other deformities that affected movements (Table 1). According to sample-size estimation for the primary objective, the study required 30 subjects. ${ }^{13}$ Before participation, subjects signed an informed consent document approved by the Office of the Khon Kaen University Ethics Committee in Human Research (HE541320).

\section{Research protocols}

The study contained two phases: (1) translation and adaptation of the tool; and (2) data collection. Details of each phase are as follows.

Translation and adaptation phase. The Th-SCIM III was translated through the method of forward and backward translation by native speakers in both languages who were not familiar with the tool. ${ }^{10}$ First, the SCIM III was

\footnotetext{
${ }^{1}$ Division of Physical Therapy, Faculty of Health Science, Srinakharin Wirot University, Nakhon-Nayok, Thailand; ${ }^{2}$ Improvement of Physical Performance and Quality of Life (IPQ) Research Group, Khon Kaen University, Khon Kaen, Thailand; ${ }^{3}$ Department of Rehabilitation Medicine, Faculty of Medicine, Khon Kaen University, Khon Kaen, Thailand and ${ }^{4}$ School of Physical Therapy, Faculty of Associated Medical Sciences, Khon Kaen University, Khon Kaen, Thailand

Correspondence: Professor S Amatachaya, School of Physical Therapy, Faculty of Associated Medical Sciences, Khon Kaen University, Khon Kaen 40002, Thailand.

E-mail: samata@kku.ac.th

Received 9 April 2015; revised 1 June 2015; accepted 1 June 2015; published online 14 July 2015
} 
Table 1 Demographic and $\mathrm{SCl}$ characteristics of the subjects

\begin{tabular}{|c|c|c|c|c|}
\hline \multirow[t]{3}{*}{ Variable } & \multicolumn{3}{|c|}{ Groups of subjects } & \multirow[t]{3}{*}{ P-value } \\
\hline & \multirow[t]{2}{*}{ Motor complete SCI (AIS A and B, $\mathrm{n}=15)$} & \multicolumn{2}{|c|}{ Motor incomplete SCl } & \\
\hline & & $A / S C(\mathrm{n}=8)$ & AIS $D(\mathrm{n}=8)$ & \\
\hline Age (years) ${ }^{a}$ & $35.80 \pm 11.64$ & $51.63 \pm 18.49$ & $52.63 \pm 17.28$ & $0.02^{\mathrm{b}}$ \\
\hline Weight (kg) ${ }^{a}$ & $60.20 \pm 12.79$ & $57.38 \pm 14.51$ & $55.75 \pm 7.42$ & 0.69 \\
\hline Height $(\mathrm{cm})^{\mathrm{a}}$ & $163.60 \pm 8.13$ & $160.75 \pm 10.10$ & $159.75 \pm 6.94$ & 0.53 \\
\hline Gender: male $(n(\%))^{c}$ & $9(60)$ & $5(63)$ & $6(75)$ & 0.77 \\
\hline Cause of injury: traumatic $(n(\%))^{c}$ & $11(73)$ & $1(13)$ & $6(75)$ & $0.01^{b}$ \\
\hline Stage of injury: chronic $(n(\%))^{c}$ & $9(60)$ & $4(50)$ & $6(75)$ & 0.60 \\
\hline Level of injury: paraplegia $(n(\%))^{c}$ & $4(27)$ & $5(63)$ & $6(75)$ & 0.83 \\
\hline Ambulatory device: WC/walker/no $(n)$ & $15 /-1-$ & $4 / 4 /-$ & $-12 / 6$ & - \\
\hline
\end{tabular}

Abbreviations: AIS, American Spinal Injury Association Impairment Scale, SCI, spinal cord injury; WC, wheelchair.

aThe data are presented using mean \pm s.d., and the findings between the groups were compared using the one-way analysis of variance.

bIndicated significant differences among the groups.
'These variables were categorized as follows: gender, male/female; cause of injury: traumatic/nontraumatic; stage of injury, subacute (post-injury time (PIT) $<12$ months)/chronic (PIT $\geqslant 12$ months); level of injury, paraplegia/tetraplegia, and the data were compared using the Kruskal-Wallis $\mathrm{H}$ test.

Table 2 Inter-tester reliability of the SCIM III Thai version

\begin{tabular}{|c|c|c|c|c|}
\hline \multirow[t]{2}{*}{ SCIM III subscales } & \multicolumn{2}{|c|}{$\begin{array}{l}\text { Motor complete SCl } \\
\qquad(\mathrm{n}=15)\end{array}$} & \multicolumn{2}{|c|}{$\begin{array}{l}\text { Motor incomplete SCl } \\
\qquad(\mathrm{n}=16)\end{array}$} \\
\hline & ICCs & $95 \% \mathrm{Cl}$ & ICCs & $95 \% \mathrm{Cl}$ \\
\hline All items & 0.994 & $0.985-0.998$ & 0.994 & $0.986-0.998$ \\
\hline Self-care & 0.988 & $0.971-0.996$ & 0.975 & $0.943-0.991$ \\
\hline $\begin{array}{l}\text { Respiration and sphincter } \\
\text { management }\end{array}$ & 0.952 & $0.887-0.983$ & 0.981 & $0.956-0.993$ \\
\hline Mobility (room and toilet) & 0.977 & $0.945-0.992$ & 0.920 & $0.815-0.970$ \\
\hline $\begin{array}{l}\text { Mobility (indoors and outdoors, } \\
\text { on even surface) }\end{array}$ & 0.983 & $0.960-0.994$ & 0.996 & $0.992-0.999$ \\
\hline
\end{tabular}

Abbreviations: $\mathrm{Cl}$, confidence interval; ICC, intraclass correlation coefficient; $\mathrm{SCI}$, spinal cord injury; SCIM, spinal cord independence measure.

translated from English to Thai by a Thai physical therapist who was fluent in English. It was then translated back into English by a native English speaker who had more than 20 years experience in Thai but was not familiar with the SCIM III. Next, the original and backward-translated versions were reviewed and compared by another native English speaker who worked in the area of biomedical sciences, but who was not familiar with the tool. Finally, the tool was refined before being used for data collection (see Appendix).

Data-collection phase. Subjects were interviewed and assessed for their demographics (including age, gender, weight and height) and SCI characteristics (including cause, stage, level and severity of SCI). ${ }^{14}$ They were then concurrently assessed for overall aspects relating to SCI using the Th-SCIM III by three physical therapists who had good clinical experience with SCI patients during the first week after admission.

\section{Data analysis}

Descriptive statistics were applied to explain the demographics and SCI characteristics of the subjects, as well as the findings of the study. The interrater reliability of the Th-SCIM III was analyzed using the intraclass correlation coefficient (ICC). An ICC of more than 0.75 was regarded as good reliability, between 0.5 and 0.75 was regarded as moderate reliability, and less than 0.5 referred to poor reliability. ${ }^{15}$ The internal consistency was assessed using Cronbach's alpha coefficients. The discriminative ability of the tool was analyzed using one-way analysis of variance. The receiver-operating characteristic curves were used to explore an optimal cutoff score, sensitivity, specificity and area under the receiver-operating characteristic curve (AUC) to discriminate the performance of subjects with motor complete and incomplete SCI. ${ }^{16}$ The level of significant differences was set at $P<0.05$.

\section{RESULTS}

\section{Subject characteristics}

Thirty-one subjects with SCI participated in the study. Fifteen had motor complete SCI (AIS A and B) and the other 16 had motor incomplete SCI (AIS $\mathrm{C}=8$ and AIS $\mathrm{D}=8$; Table 1). Most of the subjects were males $(n=20)$ at a chronic stage of injury (average postinjury time $=42.32 \pm 53.58$ months $)$ and most had paraplegia $(n=22)$. All subjects with motor complete SCI and four of those with AIS C were wheelchair bound, another subject walked with a standard walker and a personal assistant, and the other three subjects were able to walk with a standard walker over a short distance $(<100 \mathrm{~m})$. For those with AIS D, most $(n=6)$ could walk independently without any assistance or walking devices (Table 1).

\section{Inter-rater reliability}

The tool demonstrated excellent inter-rater reliability both when analyzed for overall items and separately for each subscale, and for subjects with both motor complete and motor incomplete SCI (ICC > 0.90; Table 2).

\section{Internal consistency}

The Cronbach's alpha coefficients for all items were $>0.80$ for all raters (Table 3). However, when analyzed for subscales, the Cronbach's alpha values ranged from 0.50 to 0.94 , with the lowest values for respiration and sphincter management (Table 3 ).

\section{Discriminative ability}

Subjects with AIS D had the highest Th-SCIM III scores, followed by those with AIS C, and AIS A and B, respectively (Table 4). The scores of subjects with AIS D also showed significant differences from the other groups, both when analyzed for all items and separately for each subscale, except for self-care activities. In contrast, the scores for those with AIS C were not significantly different from those with motor complete lesions (Table 4). The receiver-operating characteristic analysis demonstrated that Th-SCIM III scores of 50 and over could discriminate between subjects with motor complete and incomplete SCI (sensitivity $68.75 \%$, specificity $66.67 \%, \mathrm{AUC}=0.78,95 \%$ confidence interval $=0.62-0.95)$. 


\section{DISCUSSION}

The Th-SCIM III was translated and then assessed its reliability and discriminative ability among 31 subjects with motor complete and incomplete SCI. The findings showed that the tool had excellent interrater reliability and good internal consistency, and could significantly discriminate performance of subjects with different SCI severity (Tables 2-4). However, when analyzed for individual subscales, the scores for respiration and sphincter management had poor internal consistency (Table 3), and the scores for self-care activities were unable to discriminate performance of subjects with different degrees of lesion severity (Table 4).

Previously, the SCIM III has been translated into various languages, such as Brazilian Portuguese, Italian, Spanish and Turkish. Each version demonstrated high inter-rater reliability (ICC range $0.72-0.97$ ), acceptable to good internal consistency (Cronbach's alpha coefficients >0.70). ${ }^{9-12}$ In addition, the tool has shown high reliability when used by health professionals with different levels of experience and backgrounds, that is, physicians, nurses, physical therapists and occupational therapists. ${ }^{11}$ Except for the respiration and sphincter management subscale, the poor internal consistency may imply that the items in this subscale (that is, respiration, sphincter management for bladder and bowel and toileting) are weakly correlated to each other. In addition, the raters in the current study were physical therapists, which may have difficulties assessing bladder and bowel management that subsequently reduces internal consistency of the items.

To investigate the discriminative ability of the tool, subjects were categorized into groups according to the standard criteria of AIS classification. Subjects with AIS A and B (motor complete SCI) were those who did not have any motor function below the level of the lesion. In contrast, subjects with AIS C and D (motor incomplete SCI)

Table 3 Internal consistency of the SCIM III Thai version

\begin{tabular}{lccc}
\hline SCIM III subscales & Rater 1 & Rater 2 & Rater 3 \\
\hline All items & 0.89 & 0.89 & 0.88 \\
Self-care & 0.93 & 0.90 & 0.94 \\
Respiration and sphincter management & 0.53 & 0.59 & 0.50 \\
Mobility (room and toilet) & 0.71 & 0.72 & 0.69 \\
Mobility (indoors and outdoors, on even surface) & 0.90 & 0.90 & 0.90 \\
\hline
\end{tabular}

Abbreviation: SCIM, spinal cord independence measure.

The data are reported using Cronbach's alpha coefficients. were those who had partially preserved motor functions below the level of injury at nonfunctional and functional grades, respectively. ${ }^{14}$ The data of Th-SCIM III demonstrated that subjects with motor incomplete SCI, particularly those with AIS D, had scores higher than those with motor complete SCI (Table 4). The findings were in accordance with those reported previously. ${ }^{9}$ However, subjects with AIS C had rather low functional ability, with four of them wheelchair bound and one walked nonfunctionally (that is, could walk only a short distance with a standard walker and a personal assistant). Thus, the Th-SCIM scores that are normally used to measure the function, not impairments, showed no significant differences between subjects with AIS A and B, and C who were similarly lack functional movements below the neurological levels (Table 4). Such characteristics may also interfere with the discriminative ability of the scores for subjects with motor complete and incomplete SCI (sensitivity $68.75 \%$, specificity $66.67 \%, \mathrm{AUC}=0.78,95 \%$ confidence interval $=0.62-0.95$ ).

Findings of the current study suggest the utility of the translated tool (Th-SCIM III) for Thai health professionals. However, the findings contain some limitations. First, the number of subjects was estimated according to the primary objective (reliability test), ${ }^{13}$ and subjects in each AIS class had various levels of the lesion. Second, all raters were physical therapists and the scores of some items (bathing, dressing, and bowel and bladder management) were not directly observed; but derived from interviewing the subjects. However, the researchers attempted to minimize errors of the information given by the confirmation with their caregivers, and medical and nursing records. Riberto et al. ${ }^{11}$ reported that the SCIM III can be used by health professionals with different levels of experience and different backgrounds. The scores can be obtained by an interview or by direct observation of the subject while he or she performs the tasks. ${ }^{11}$ The researchers in the present study believe that further studies with a larger number of subjects with various degrees of lesion severity and levels of the lesion, or multicenter trials, as well as exploration of other psychometric properties (that is, intra-rater reliability, discriminative ability in subjects with different levels of the lesion, smallest real difference and s.e. of measurement) may fulfill the utility of the Th-SCIM III in clinical practice.

\section{CONCLUSION}

Findings of this study support the use of the Th-SCIM III to assess daily functions of patients with SCI. Therefore, these findings may be useful for Thai health professionals who are not fluent in English.

Table 4 Scores of SCIM III Thai version of subjects with different degrees of lesion severity

\begin{tabular}{|c|c|c|c|c|}
\hline \multirow[t]{3}{*}{ Variables } & \multicolumn{3}{|c|}{ Groups of subjects } & \multirow[t]{3}{*}{ P-value } \\
\hline & \multirow[t]{2}{*}{ Motor complete SCI (AIS A and B, $\mathrm{n}=15$ ) } & \multicolumn{2}{|c|}{ Motor incomplete SCI } & \\
\hline & & $A / S C(n=8)$ & AIS D $(\mathrm{n}=8)$ & \\
\hline All items & $38.93 \pm 16.81$ & $48.13 \pm 11.62$ & $82.75 \pm 19.77^{A B, C}$ & $0.00^{a}$ \\
\hline Self-care & $11.53 \pm 6.10$ & $12.38 \pm 3.85$ & $17.13 \pm 4.76$ & 0.06 \\
\hline Respiration and sphincter management & $16.93 \pm 4.32$ & $24.25 \pm 8.26$ & $33.50 \pm 8.90^{A B, C}$ & $0.00^{a}$ \\
\hline Mobility (room and toilet) & $5.47 \pm 4.12$ & $5.63 \pm 2.50$ & $9.13 \pm 1.23^{\mathrm{AB}}$ & $0.04^{a}$ \\
\hline Mobility (indoors and outdoors, on even surface) & $5.00 \pm 3.14$ & $5.88 \pm 3.87$ & $23.00 \pm 10.73^{\mathrm{AB}, \mathrm{C}}$ & $0.00^{\mathrm{a}}$ \\
\hline
\end{tabular}

Abbreviations: AIS, American Spinal Injury Association Impairment Scale; SCIM, spinal cord independence measure.

alndicates significant differences.

The data are presented using mean \pm s.d. P-values from the one-way analysis and every pairwise comparison were analyzed using the Scheffe test. Superscripts indicate the group(s) with significant differences from the indicated groups where $A B=$ subjects with AIS $A$ and $B$, and $C=$ subjects with AIS $C$. 
However, further research is needed to confirm the clinical implications of this tool.

\section{DATA ARCHIVING}

There were no data to deposit.

\section{CONFLICT OF INTEREST}

The authors declare no conflict of interest.

\section{ACKNOWLEDGEMENTS}

This study was supported by the Improvement of Physical Performance and Quality of Life (IPQ) research groups at Khon Kaen University. The researchers thank Mr Ian Thomas and Dr Jeffrey Roy Johns for their help in translation of the tool.

1 van den Berg-Emons RJ, Bussmann JB, Haisma JA, Sluis TA, van der Woude LH, Bergen MP et al. A prospective study on physical activity levels after spinal cord injury during inpatient rehabilitation and the year after discharge. Arch Phys Med Rehabil 2008; 89: 2094-2101.

2 Haisma JA, Bussmann JB, Stam HJ, Sluis TA, Bergen MP, Dallmeijer AJ et al. Changes in physical capacity during and after inpatient rehabilitation in subjects with a spinal cord injury. Arch Phys Med Rehabil 2006; 87: 741-748.

3 Wirth B, van Hedel H, Kometer B, Dietz V, Curt A. Changes in activity after a complete spinal cord injury as measured by the spinal cord independence measure II (SCIM II). Neurorehabil Neural Repair 2008; 22: 145-153.

4 Cardenas DD, Hoffman JM, Kirshblum S, McKinley W. Etiology and incidence of rehospitalization after traumatic spinal cord injury: a multicenter analysis. Arch Phys Med Rehabil 2004; 85: 1757-1763.
5 Catz A, Itzkovich M, Agranov E, Ring H, Tamir A. SCIM-spinal cord independence measure: a new disability scale for patients with spinal cord lesions. Spinal Cord 1997; 35: 850-856.

6 Catz A, Itzkovich M, Steinberg F, Philo O, Ring H, Ronen J et al. The Catz-Itzkovich SCIM: a revised version of the Spinal Cord Independence Measure. Disabil Rehabil 2001; 23: 263-268.

7 Catz A, Itzkovich M, Tesio L, Biering-Sorensen F, Weeks C, Laramee MT et al. A multicenter international study on the Spinal Cord Independence Measure, version III: Rasch psychometric validation. Spinal Cord 2007; 45: 275-291.

8 Itzkovich M, Gelernter I, Biering-Sorensen F, Weeks C, Laramee MT, Craven BC et al. The Spinal Cord Independence Measure (SCIM) version III: reliability and validity in a multi-center international study. Disabil Rehabil 2007; 29: 1926-1933.

9 Invernizzi M, Carda S, Milani P, Mattana F, Fletzer D, Iolascon G et al. Development and validation of the Italian version of the Spinal Cord Independence Measure III. Disabil Rehabil 2010; 32: 1194-1203.

10 Kesiktas N, Paker N, Bugdayci D, Sencan S, Karan A, Muslumanoglu L. Turkish adaptation of Spinal Cord Independence Measure-version III. Int J Rehabil Res 2012; 35: 88-91.

11 Riberto M, Tavares DA, Rimoli JR, Castineira CP, Dias RV, Franzoi AC et al. Validation of the Brazilian version of the Spinal Cord Independence Measure III. Arq Neuropsiquiatr 2014; 72: 439-444.

12 Zarco-Perinan MJ, Barrera-Chacon MJ, Garcia-Obrero I, Mendez-Ferrer JB, Alarcon LE, Echevarria-Ruiz de Vargas C. Development of the Spanish version of the Spinal Cord Independence Measure version III: cross-cultural adaptation and reliability and validity study. Disabil Rehabil 2014; 36: 1644-1651.

13 Morrow JR, Jackson AW. How "significant" is your reliability? Res Q Exerc Sport 1993; 64: 352-355

14 Maynard FM Jr, Bracken MB, Creasey G, Ditunno JF Jr, Donovan WH, Ducker TB et al. International Standards for Neurological and Functional Classification of Spinal Cord Injury. American Spinal Injury Association. Spinal Cord 1997; 35: 266-274.

15 Portney LG, Watkins MP. Fountations of Clinical Research: Applications to Practice. Prentice Hall: Upper Saddle River, NJ, USA, 2009.

16 Akobeng AK. Understanding diagnostic tests 3: receiver operating characteristic curves. Acta Paediatr 2007; 96: 644-647. 


\section{APPENDIX}

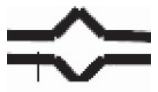

שירותי בריאוות $\pi \cdot>>=$
LOEWENSTEIN HOSPITAL REHABILITATION CENTER

Affiliated with the Sackler Faculty of Medicine, Tel-Aviv University

แผนก 5 ผู้อำนวยการการแพทย์: Dr. Amiram Catz Tel: 972-9-7709090 Fax: 972-9-7709986 e-mail: amiramc@clalit.org.il (ผู้ได้รับอนุญาตการแปล อ.ดร.จิราภรณ์ วรรณปะเข สาขากายภาพบำบัด คณะสหเวชศาสตร์ มหาวิทยาลัยศรีนครินทรวิโรฒ e-mail: j wannapakhe@hotmail.com รศ.ดร.สุกัลยา อมตฉายา สายวิชากายภาพบำบัด คณะเทคนิคการแพทย์ มหาวิทยาลัยขอนแก่น e-mail: samata@kku.ac.th) ชื่อผู้ป่วย: .รหัสประจำตัวผู้ป่วย ..ชื่อผู้ประเมิน:...

(ใส่คะแนนสำหรับแต่ละหน้าที่ไว้ในช่องสี่เหลี่ยมใต้วันที่ แบบฟอร์มนี้ใช้สำหรับการประเมินได้ถึง 6 ครั้ง)

\section{SCIM-SPINAL CORD INDEPENDENCE MEASURE} การดูแลตัวเอง (Self-Care)

1. การรับประทานอาหาร (การตัดอาหาร การเปิดภาชนะบรรจุ การเทอาหาร การนำอาหารเข้าปาก การถือแก้วที่บรรจุของเหลว)

0. รับอาหารทางสายยาง เจาะหน้าท้อง หรือต้องการความช่วยเหลือในการรับประทานอาหารทั้งหมด

1. ต้องการความช่วยเหลือบางส่วนในการรับประทานอาหารและ/หรือการดื่มน้ำ หรือการใส่อุปกรณ์ช่วย

2. รับประทานอาหารได้เอง ต้องการอุปกรณ์ช่วยหรือความช่วยเหลือเพียงการตัดอาหาร และ/หรือการเท และ/หรือการเปิดภาชนะ

3. รับประทานอาหารหรือดื่มน้ำได้เอง ไม่ต้องการความช่วยเหลือหรืออุปกรณ์ช่วย

2. การอาบน้ำ (การถูสบู่ การล้างตัว การเช็ดตัวและศีรษะ การเปิดก๊อกน้ำ) ก - ร่างกายส่วนบน; ข - ร่างกายส่วนล่าง

ก. 0 . ต้องการความช่วยเหลือทั้งหมด

1. ต้องการความช่วยเหลือบางส่วน

2. อาบน้ำได้เองโดยใช้อุปกรณ์ช่วยหรือในบริเวณที่จัดทำขึ้นเฉพาะ (ที่ไม่ใช้สำหรับคนสุขภาพดี เช่น มีราวเกาะยึด เก้าอี้) (adss)

3. อาบน้ำได้เอง ไม่ต้องใช้ adss

ข. 0 . ต้องการความช่วยเหลือทั้งหมด

1. ต้องการความช่วยเหลือบางส่วน

2. อาบน้ำได้เองโดยใช้ $\mathrm{adss}$

3. อาบน้ำได้เอง ไม่ต้องใช้ $a d s s$

3. การใส่เสื้อผ้า (เสื้อผ้า รองเท้า อุปกรณ์เสริมที่ใช้ถาวร: การแต่งตัว การใส่ การถอด) ก - ร่างกายส่วนบน; ข - ร่างกายส่วนล่าง

ก. 0 . ต้องการความช่วยเหลือทั้งหมด

1. ต้องการความช่วยเหลือบางส่วนสำหรับการสวมใส่เสื้อผ้าที่ไม่มีกระดุม ซิป หรือเชือกผูก (cwobz" $\left.{ }^{* *}\right)$

2. สวมใส่เสื้อผ้าแบบ cwobzl ได้เอง ต้องการ adss

3. สวมใส่เสื้อผ้าแบบ cwobzl ได้เอง ไม่ต้องการ adss ต้องการความช่วยเหลือหรือ adss เพียงสำหรับ bzl

4. สวมใส่เสื้อผ้าทุกแบบได้เอง ไม่ต้องการ adss

ข. 0 . ต้องการความช่วยเหลือทั้งหมด

1. ต้องการความช่วยเหลือบางส่วนสำหรับการสวมใส่เสื้อผ้าที่ไม่มีกระดุม ซิป หรือเชือกผูก (cwobzl $\left.l^{* *}\right)$

2. สวมใส่เสื้อผ้าแบบ cwobzl ได้เอง ต้องการ adss

3. สวมใส่เสื้อผ้าแบบ cwobzl ได้เอง ไม่ต้องการ $a d s s$ ต้องการความช่วยเหลือหรือ $a d s s$ เพียงสำหรับ bzl

4. สวมใส่เสื้อผ้าทุกแบบได้เอง ไม่ต้องการ adss

4. การแต่งตัว (การล้างมือและหน้า แปรงฟัน หวีผม โกนหนวด แต่งหน้า)

0. ต้องการความช่วยเหลือทั้งหมด

1. ต้องการความช่วยเหลือบางส่วน

2. แต่งตัวได้เองโดยใช้อุปกรณ์ช่วย

3. แต่งตัวได้เองโดยไม่ใช้อุปกรณ์ช่วย

คะแนนรวมย่อย $(0-20)$

หมายเหตุ ${ }^{*} \mathrm{adss}=$ อุปกรณ์ช่วยหรือในบริเวณที่จัดทำขึ้นเฉพาะ (adaptive devices or specific setting) " $\mathrm{cwobzl}=$ เสื้อผ้าที่ไม่มีกระดุม ซิบ หรือเชือกผูก (clothes without buttons, zipps or laces) 
5. การหายใจ

0. ต้องใส่ท่อผ่านหลอดลม (tracheal tube: T) และต้องใช้เครื่องช่วยหายใจแบบถาวรหรือเป็นระยะ (intermittent assisted ventilator: $\mid \mathrm{AV})$

2. หายใจได้เองร่วมกับ $\Pi$; ต้องการออกซิเจน ความช่วยเหลือในการไอหรือการจัดการ $\Pi$ อย่างมาก

4. หายใจได้เองร่วมกับ $\Pi$; ต้องการออกซิเจน ความช่วยเหลือในการไอหรือการจัดการ $\Pi$ เล็กน้อย

6. หายใจได้เองโดยไม่ใช้ $T$; ต้องการออกซิเจน ความช่วยเหลืออย่างมากในการไอ หน้ากาก (เช่น peep) หรือ IAV (bipap)

8. หายใจได้เองโดยไม่ใช้ $T$; ต้องการความช่วยเหลือเพียงเล็กน้อย หรือการกระตุ้นการไอ

10. หายใจได้เองโดยไม่ต้องการความช่วยเหลือหรืออุปกรณ์ช่วย

6. การจัดการหูรูด - กระเพาะปัสสาวะ

0. ต้องคาสายสวนปัสสาวะ

3. ปัสสาวะคงค้างในกระเพาะปัสสาวะ (residual urine volume: RUV) $>100$ ซีซี; ไม่ต้องสวนปัสสาวะเป็นประจำ หรือต้องช่วยสวน ปัสสาวะแบบเป็นระยะ

6. RUV < 100 ซีซี หรือสวนปัสสาวะแบบเป็นระยะด้วยตนเอง; ต้องการความช่วยเหลือในการใช้อุปกรณ์ระบายปัสสาวะ

9. สวนปัสสาวะแบบเป็นระยะด้วยตนเอง ใช้อุปกรณ์ระบายปัสสาวะภายนอกได้เอง

11. สวนปัสสาวะแบบเป็นระยะด้วยตนเอง กลั้นปัสสาวะระหว่างการสวนแต่ละครั้งได้ ไม่ต้องใช้อุปกรณ์ระบายปัสสาวะภายนอก

13. $R U V<100$ ซีซี ต้องการเพียงอุปกรณ์ระบายปัสสาวะภายนอก โดยไม่ต้องการความช่วยเหลือในการระบายปัสสาวะ

15. $R U V<100$ ซีซี สามารถกลั้นปัสสาวะได้ โดยไม่ต้องใช้อุปกรณ์ระบายปัสสาวะภายนอก

7. การจัดการหูรูด - การขับถ่ายอุจจาระ

0. ถ่ายอุจจาระไม่เป็นเวลาหรือนานๆ ครั้ง (น้อยกว่า 1 ครั้งใน 3 วัน)

5. ถ่ายอุจจาระเป็นเวลา แต่ต้องการความช่วยเหลือ (เช่น การใส่ยาเหน็บทวาร) มีการราดน้อย (น้อยกว่า 2 ครั้ง/เดือน)

8. ถ่ายอุจจาระเป็นปกติ ไม่ต้องการความช่วยเหลือ มีการราดน้อย (น้อยกว่า 2 ครั้ง/เดือน)

10. ถ่ายอุจจาระเป็นปกติ ไม่ต้องการความช่วยเหลือ ไม่มีการราด

8. การใช้ห้องน้ำ (การทำความสะอาด การจัดเสื้อผ้าก่อนและหลัง การใช้กระดาษชำระ)
0. ต้องการความช่วยเหลือทั้งหมด
1. ต้องการความช่วยเหลือบางส่วน ไม่สามารถทำความสะอาดได้เอง
2. ต้องการความช่วยเหลือบางส่วน สามารถทำความสะอาดได้เอง
4. สามารถใช้ห้องน้ำได้เอง แต่ต้องใช้อุปกรณ์ช่วยหรือบริเวณที่ทำไว้เฉพาะ (เช่น ราว)
5. สามารถใช้ห้องน้ำได้เอง ไม่ต้องใช้อุปกรณ์ช่วยหรือบริเวณที่ทำไว้เฉพาะ

คะแนนรวมย่อย (0-40)

\section{ความสามารถในการเคลื่อนไหว (ในห้องและห้องน้ำ) [Mobility (room and toilet)]}

9. การเคลื่อนไหวบนเตียงและการป้องกันแผลกดทับ (การพลิกลำตัวส่วนบน การพลิกลำตัวส่วนล่าง การลุกขึ้นนั่งบนเตียง การยกตัวในรถเข็นนั่ง โดยใช้หรือไม่ใช้อุปกรณ์ช่วย ที่ไม่ใช่อุปกรณ์ช่วยไฟฟ้า)
0. ต้องการความช่วยเหลือทั้งหมด
2. สามารถทำได้ 1 กิจกรรมโดยไม่ต้องการความช่วยเหลือ
4. สามารถทำได้ 2 หรือ 3 กิจกรรมโดยไม่ต้องการความช่วยเหลือ
6. สามารถเคลื่อนไหวบนเตียงและเคลื่อนไหวเพื่อลดแรงกดทับได้เองทั้งหมด

10. การเคลื่อนย้ายตัวระหว่างเตียงและรถเข็นนั่ง (การล็อครถเข็นนั่ง การยกที่วางเท้า การถอดและปรับที่วางแขน การเคลื่อนย้ายตัว การยกเท้า)
0. ต้องการความช่วยเหลือทั้งหมด
1. ต้องการความช่วยเหลือบางส่วน และ/หรือการดูแล และ/หรืออุปกรณ์ช่วย (เช่น แผ่นเลื่อนตัว)
2. ทำได้เอง (หรือไม่ต้องใช้รถเข็นนั่ง) 


\section{1. การเคลื่อนย้ายตัวระหว่างรถเข็นนั่ง ห้องน้ำ อ่างอาบน้ำ}

(หากใช้รถเข็นนั่งแบบมีที่ขับถ่าย ให้ดูการเคลื่อนย้ายตัวไป-กลับ หากใช้รถเข็นนั่งแบบปกติ ให้ดูการล็อครถเข็นนั่ง

การเปิดที่วางเท้า การถอดและปรับที่วางแขน การเคลื่อนย้ายตัว และการยกเท้า)
0 . ต้องการความช่วยเหลือทั้งหมด
1. ต้องการความช่วยเหลือบางส่วน และ/หรือการดูแล หรืออุปกรณ์ช่วย (เช่น ราวจับ)
2. ทำได้เอง (หรือไม่ต้องใช้รถเข็นนั่ง)

\section{การเคลื่อนไหว (ภายในและภายนอกบ้าน บนพื้นที่ระดับเดียวกัน) [Mobility (indoors and outdoors, on even surface)]}

\section{2. การเคลื่อนไหวภายในบ้าน}
0 . ต้องการความช่วยเหลือทั้งหมด
1. ต้องใช้รถเข็นไฟฟ้าหรือความช่วยเหลือบางส่วนในการใช้รถเข็นนั่งแบบธรรมดา
2. เคลื่อนไหวได้เองโดยใช้รถเข็นนั่งแบบธรรมดา
3. ต้องการการดูแลขณะเดิน (โดยใช้หรือไม่ใช้อุปกรณ์ช่วย)
4. เดินได้โดยโครงเหล็กช่วยเดินหรือไม้ค้ำยัน (เดินแบบเหวี่ยงตัว)
5. เดินได้โดยใช้ไม้ค้ำยันหรือไม้เท้า 2 อัน (เดินแบบก้าวขาสลับกัน)
6. เดินได้โดยใช้ไม้เท้า 1 อัน
7. ต้องการกายอุปกรณ์เสริมสำหรับขาเท่านั้น
8. เดินได้โดยไม่ต้องใช้อุปกรณ์ช่วย

13. การเคลื่อนไหวระยะทางขนาดกลาง (10-100 เมตร)
0 . ต้องการความช่วยเหลือทั้งหมด
1. ต้องใช้รถเข็นไฟฟ้าหรือความช่วยเหลือบางส่วนในการใช้รถเข็นนั่งแบบธรรมดา
2. เคลื่อนไหวได้เองโดยใช้รถเข็นนั่งแบบธรรมดา
3. ต้องการการดูแลขณะเดิน (โดยใช้หรือไม่ใช้อุปกรณ์ช่วย)
4. เดินได้โดยโครงเหล็กช่วยเดินหรือไม้ค้ำยัน (เดินแบบเหวี่ยงตัว)
5. เดินได้โดยใช้ไม้ค้ำยันหรือไม้เท้า 2 อัน (เดินแบบก้าวขาสลับกัน)
6. เดินได้โดยใช้ไม้เท้า 1 อัน
7. ต้องการกายอุปกรณ์เสริมสำหรับขาเท่านั้น
8. เดินได้โดยไม่ต้องใช้อุปกรณ์ช่วย

14. การเคลื่อนไหวนอกบ้าน (มากกว่า 100 เมตร)
0. ต้องการความช่วยเหลือทั้งหมด
1. ต้องใช้รถเข็นไฟฟ้าหรือความช่วยเหลือบางส่วนในการใช้รถเข็นนั่งแบบธรรมดา
2. เคลื่อนไหวได้เองโดยใช้รถเข็นนั่งแบบธรรมดา
3. ต้องการการดูแลขณะเดิน (โดยใช้หรือไม่ใช้อุปกรณ์ช่วย)
4. เดินได้โดยโครงเหล็กช่วยเดินหรือไม้ค้ำยัน (เดินแบบเหวี่ยงตัว)
5. เดินได้โดยใช้ไม้ค้ำยันหรือไม้เท้า 2 อัน (เดินแบบก้าวขาสลับกัน)
6. เดินได้โดยใช้ไม้เท้า 1 อัน
7. ต้องการกายอุปกรณ์เสริมสำหรับขาเท่านั้น
8. เดินได้โดยไม่ต้องใช้อุปกรณ์ช่วย

\section{5. การใช้บันได}
0. ไม่สามารถขึ้นหรือลงบันไดได้
1. ขึ้นและลงบันไดได้อย่างน้อย 3 ขั้น โดยใช้ความช่วยเหลือหรือการดูแลจากผู้อื่น
2. ขึ้นและลงบันไดได้อย่างน้อย 3 ขั้น โดยการเกาะราวบันได และ/หรือใช้ไม้ค้ำยันหรือไม้เท้า
3. ขึ้นและลงบันไดได้อย่างน้อย 3 ขั้น โดยไม่ต้องการความช่วยเหลือหรือการดูแล 
16. การเคลื่อนย้ายตัวระหว่างรถเข็นนั่งและรถยนต์

(การนำรถเข็นเข้าใกล้รถยนต์ การล็อครถเข็น การถอดที่วางแขนและที่วางเท้า การเคลื่อนย้ายตัวไปและออกจากรถยนต์ การนำรถเข็นนั่งเข้าเก็บและนำออกจากรถยนต์)

0. ต้องการความช่วยเหลือทั้งหมด

1. ต้องการความช่วยเหลือหรือการดูแลบางส่วน หรือต้องใช้อุปกรณ์ช่วย

2. เคลื่อนย้ายตัวได้เองโดยไม่ต้องใช้อุปกรณ์ช่วย (หรือไม่ต้องใช้รถเข็นนั่ง)

17. การเคลื่อนย้ายตัวระหว่างพื้นและรถเข็นนั่ง

0 . ต้องการความช่วยเหลือ

1. เคลื่อนย้ายตัวได้เองโดยใช้หรือไม่ใช้อุปกรณ์ช่วย (หรือไม่ต้องใช้รถเข็นนั่ง)

คะแนนรวมย่อย $(0-40)$

คะแนน SCIM รวม (0-100) 